\title{
Epidemiological risks in operating theatre
}

\author{
Zagrożenia epidemiologiczne na bloku operacyjnym
}

\section{Jolanta Sułek $k^{1,2}$ ๑}

${ }^{1}$ Uniwersytet Jagielloński CM, Wydział Nauk o Zdrowiu, Kraków/Jagiellonian University CM, Faculty of Health Sciences, Cracow ZUniwersytecki Szpital Ortopedyczno-Rehabilitacyjny UJCM, Zakopane/The Orthopedic-Rehabilitation University Hospital in, Zakopane

CORRESPONDING AUTHOR/AUTOR DO KORESPONDENCJ:

Jolanta Sułek

Uniwersytecki Szpital Ortopedyczno-Rehabilitacyjny UJCM, Zakopane

ul. Oswalda Balzera 15, 34-500 Zakopane e-mail:jola.sulek@poczta.fm

Słowa kluczowe:

\section{ABSTRACT}

Key words:

\section{ABSTRACT}

STRESZCZENIE

Key words:

\section{ZAGROŻENIA EPIDEMIOLOGICZNE NA BLOKU OPERACYJNYM}

Wprowadzenie. Pacjent poddawany zabiegowi operacyjnemu jest obarczony ryzykiem infekcji dodatkowo wikłającej jego sytuację zdrowotną. Powoduje to wiele negatywnych konsekwencji w postaci pogorszenia sytuacji zdrowotnej pacjenta i wydłużenia jego pobytu w szpitalu a nawet śmierci, ale także wpływa na negatywną ocenę jakości świadczonych usługi i podnoszenie kosztów leczenia. Cel pracy. Celem artykułu była analiza sytuacji epidemiologicznej pacjenta poddawanego zabiegowi operacyjnemu pod kątem źródeł infekcji śródoperacyjnych. Cele szczegółowe: elementy stanowiące zagrożenie epidemiologiczne ze strony pacjenta; elementy stanowiące zagrożenie epidemiologiczne ze strony personelu; elementy stanowiące zagrożenie epidemiologiczne z powodu specyfiki pracy na boku operacyjnym.

Metoda. Zastosowano analizę piśmiennictwa - praca poglądowa.

Wnioski. 1) zakażenia, które mają swoje źródła na bloku operacyjnym mogą wynikać z różnych przyczyn; 2) do występowania infekcji może się przyczyniać czynnik ludzki (pacjent i personel), ale także czynnik organizacyjny; 3) znaczącym powodem infekcji mogą być nieskuteczne procedury lub brak znajomości/nieprzestrzeganie procedur przez personel.

źródła zakażeń, blok operacyjny, czynniki ryzyka

\section{EPIDEMIOLOGICAL RISKS IN OPERATING THEATRE}

Introduction. A patient submitted to a surgical procedure is at a high risk of an infection which might additionally worsen his or her health condition. Such infection may cause plenty of negative consequences, such as patient's health deterioration, which prolongs his or her hospital stay or even death. It can also cause a patient's negative opinion about hospital care he or she has received and, what is more, it increases the cost of treatment.

Aim. The aim of the article is the epidemiological situation analysis of a patient submitted to a surgical procedure which was done from an angle of the sources of mid-surgical infections. Specific aims: a patient related elements causing epidemiological risk; hospital staff related elements causing epidemiological risk; specific character of an operating theatre procedures related elements causing epidemiological risk.

Methods. Literature analysis - review paper.

Conclusions. 1) the infections, which have their source in an operating theatre, may result from various reasons; 2) the cause of an infection might be a human factor (patient, staff) but also organisational factors; 3 ) a substantial cause of an infection might be ineffective procedures, lack of knowledge of the procedures or simply not observing them by the hospital staff.

infections, operating theatre, risk factors 


\section{INTRODUCTION}

Every patient undergoing a surgical treatment is vulnerable to infection which may complicate his/her condition even more. Due to obvious reasons, the threat of infection is much higher in the case of urgent surgeries and in patients with severe disorders and those unprepared for surgical interventions [1]. All these factors drastically increase the risk of infection, if only because of the fact that the time of patient preparation for a surgery is much shorter, in particular when it is carried out in the emergency room mode due to an injury suffered in an accident. Standard procedure involving antibiotic therapy [2] before skin incision and in the course of surgery may appear to be insufficient. Microbial isolates from wound swabs obtained in operating theatres include in particular: Escherichia Coli (22.8\%), Enterococcus spp. (19.1\%), Klebsiella Pneumoniae (8.5\%), Enterobacter spp. (7.7\%), Coagulase-Negative Staphylococci (7.3\%), Pseudomonas Aeruginosa (7.2\%), Staphilococcus Aureus (4.9\%), Proteus Vulgaris (4.4\%), Morganella Morganii (4.2\%), Acinetobacter Baumanii (3.6\%), Streptococcus spp. (3.5\%), Citrobacter Freundii (2.6\%), Candida spp. (2.3\%), Serratia Marescens (1.2\%) and Stenotrophomonas Maltophilia (0.7\%) [3].

Part of those microorganisms belong to drug-resistant strains [4]. Mechanical ventilation may also be one of the potential routes of infection [5]. Here, a good solution is the use of disposable breathing circuits and filters changed after every patient when general anesthesia is applied.

Threats posed by general health condition, course of surgery and patient microbiological potential

During a surgery, responsibility for the patient is borne by the team of anesthesiologists and surgeons. Obviously, operating theatre personnel should make every effort to ensure patient's safety while performing medical procedures. Epidemiological safety is an element of this process, too [5].

Current research [3] shows that the factors that may seriously affect epidemiological safety of the patient in the operating theatre are as follows: patient's age, sex, body weight, operation site and type of surgical procedure, general condition of the patient (above class 3 according to the American Society of Anesthesiologists), patient's tobacco addiction, operator's experience (short experience increases the risk of patient infection), type of incision instrument, length of surgery - over four hours, drain in the wound after surgery, blood transfusion during surgery and wound mesh left inside [6].

Another risk factor in infections is that of the microorganisms present in patient's breathing tract. Here, the care of patient's oral cavity is the simplest and most effective strategy of VAP (Ventilator Associated Pneumonia) reduction in patients requiring mechanical ventilation. Microbes causing gum and periodontal diseases are permanently present in the oral cavity, so their total removal is practically impossible. Most microbes living in the oral cavity constitutes physiological bacterial florae. Research shows that no oral care for 10-21 days causes plaque accumulation, which, in turn, leads to gingivitis $[7,8,9]$.
Accurate implementation of the standards for hospital-acquired infection prevention and control contributes to therapy cost reduction [10]. In Poland, the annual cost of hospital-acquired infections is 800 million PLN [11]

\section{Threats posed by the specific risks involved in operating room activity}

Apart from the circumstances indicated above, there are other factors that directly affect epidemiological safety in the operating room. These can be divided into human and organizational factors.

Organizational factors include:

- habits associated with hospital procedure compliance;

- time pressure and following surgery schedules;

- technical faults and failures, for example: operating room door (faulty air conditioning system or disturbances in its operation);

- inappropriate temperature control in the operating room (too low temperature causes patient's hypothermia) [12];

type of anesthesia used - (central blockade whose mechanism of operation causes increased loss of temperature through dilated blood vessels) [13].

Insufficient knowledge of the applicable procedures and standards or their negligence due to other reasons may result in cross infection (transfer of harmful microorganisms on other patients) [14].

Procedures eliminating the risk of organizational factors

The most essential elements in the prevention and control of infections which affect patient's safety in medical facilities include:

- effective washing, disinfection and sterilization of medical instruments and equipment of multiple use;

- observing the rules for storage and transport of disposable and multiple use medical products;

- disinfection of surfaces in direct contact with the patient or biological material coming from the patient; - disinfection of rooms and their equipment [15].

Failure to observe or omission of any of the foregoing elements may lead to the risk of transferring infection on the patient. Ill-understood economizing or hurrying sometimes make medical personnel skip apparently simple activities, which may have far-reaching consequences for the patient.

Human factors include:

- on the part of the patient - immunodeficiency and further decline of immunity caused by: skin incision (gateway of infection), stress induced by surgery or hypothermia during surgery [16];

- on the part of medical personnel - infections, routine, ignorance of procedures because of side-effects (atopic skin symptoms, respiratory tract lesions) [17]. 
Sanitary regime compliance by all members of medical staff may have a vital impact on the complications related to hospital infections. Nurses employed in the operating theatre should perform their duties with due care and diligence and in compliance with the applicable procedures and standards. Their activity should be guided by responsibility for the life and health of inpatients. Continuous education is absolutely indispensable to eliminate professional routine and negative attitudes which may contribute to increased risk of infection [18].

Procedures minimalizing epidemiological threat due to human factor

Hand hygiene practices is of vital importance for minimalizing iatrogenic hospital infection rates. Staff hands are the main route of infection transmission. Correct hand hygiene should become an inherent part of clinical practice for anesthesiologists. Accordingly, one of the key aspects of proper hand hygiene is wearing short, unpolished nails and taking off jewelry.

Diagnostics and sterile glows should be available at all times. It must also be remembered that using gloves does not free personnel from the obligation of hand disinfection. It has been well-known fact, since Ignaz Semmelweis's times, that correct hand hygiene is a decisive factor for the prevention of infections spred by medical personnel. The threat of defenselessness against multidrug-resistant microorganisms made theoreticians and practitioners give more attention to hand hygiene with the view to patient safety. For many decades specialists dealing with hospital infection control have been trying to reach a high level of hand hygiene protocol compliance, but despite various attempts and actions, this level still remains rather low. Numerous publications can be found in medical literature that analyze the reasons for low rate of hand hygiene compliance by medical staff, including physicians. These are in particular: overwork and constant rush, ignorance of hygiene relevance, lack of positive models, deficient knowledge of hand hygiene and "incorrectly performed procedures". Nursing staff, more frequently than physicians, carries out hand washing procedures effectively and treats them as part of routine. It is also worth paying attention to the role of a mentor. Observational studies show that if the leader of a team ignored applicable procedures, other team member also failed to follow them with due care. Tired and busy personnel concentrates on other activities and treats hand hygiene as something of minor importance [19].

Hair, eye and face protection is another key element in minimizing infection rates, both among personnel and patients. In the operating room environment, it is recommended to use caps changed after every surgery. During invasive procedures, sterile operating room clothing must be used and contaminated clothing must be changed as soon as possible [5].

Another factor affecting transmission of infections is inappropriate dealing with medications and equipment used for their administration. Rules for medicine preparation, administration and storage must be strictly observed. Syringes and other devices connected to vascular cathe- ters should be treated as contaminated. Other equipment of the anesthesia work station also constitutes a potential transmission route of infection. Packages with disposable equipment should be opened right before its use. Surfaces of anesthetic apparatuses and monitors should be treated as contaminated. They ought to be regularly cleaned and always between subsequent patients. Disposable equipment should be used whenever possible [20].

Special attention must be paid to intubation equipment. It is recommended to use disposable laryngoscope handles and disposable guides for complicated multiple intubations.

To reduce infection rates, it is also recommended to use nursing intervention packages with systemic assessment of clinical procedures [5]. It is emphasized that among special factors of infection risk related to hospitalization, there are such procedures as: urinary bladder catheterization, vascular catheter insertion and dealing with intubated patients [21].

Among the factors that may cause a decrease of patient's immunity there is unintended perioperative hypothermia. The condition of reduced temperature falling below $36 \mathrm{oC}$ is called perioperative hypothermia, which is one of the complications connected with anesthesia and surgical treatment. According to the research carried out in this field, unintended perioperative hypothermia occurs in $50-90 \%$ of operated patients. Complications related to hypothermia include disorders of respiratory system, cardiovascular system, coagulation and electrolytes, higher vulnerability to infections, disturbed wound healing or limited drug metabolism. Hypothermia affects the incidence of surgical site infections and the pace of wound healing. In a range of publications, it has been shown that disturbed body temperature has an impact on the immune system. Reduced deep temperature disturbs leucopoiesis, has a negative effect on immunoglobulin production and leads to impaired coagulation. Hypothermia triples the risk of surgical site infection. In this case, the causes of infections have different background. On the one hand, there is limited oxygen supply to the surgical site (vasoconstriction) and on the other hand, there is patient's immune system response [22, 23, 24, 25]. Using procedures intended to maintain patient's body temperature on the right level is the task for the entire surgical team.

Operating theatre is a self-contained hospital section of the highest cleanliness. Following procedures and protocols, along with ensuring the conduct appropriate for the operating theater staff can make this zone safe for the patient and the medical team [5].

\section{CONCLUSIONS}

Infections induced by a factor coming from the operating theatre are a serious problem which markedly affects patient's condition, prognosis, other complications and consequently, final therapeutic outcomes and their evaluation. Prevention measures taken to protect patients or, when no such protection is possible, decrease their vulnerability, often seem to be inefficient or insufficient. 
Searching for the sources of failures in the fight against the risk of infection in the operating theatre is one of the priorities aiming at improved quality of the services provided to patients. The origins of failures in this area may be put down to imperfect procedures, deficient work organization, technical faults, medical staff routine or, on the contrary - short seniority and lack of experience.
Yet, the infection potential, whose source is the patient, cannot be forgotten. In this context, complete elimination of threats seems impossible, despite upgrading procedures, trainings or organizational and technical improvements.

\section{Zagrożenia epidemiologiczne na bloku operacyjnym}

\section{WPROWADZENIE}

Pacjent poddawany zabiegowi operacyjnemu obarczony jest ryzykiem infekcji, dodatkowo wikłającej jego sytuację zdrowotną. Z oczywistych względów, zagrożenie to jest o wiele większe w przypadku zabiegów wykonywanych w trybie nagłym, u pacjenta obarczonego ciężkimi schorzeniami, a także nieprzygotowanego do zabiegu operacyjnego[1]. Powyższe czynniki zdecydowanie podnoszą ryzyko dodatkowego zakażenia, choćby $\mathrm{z}$ tego powodu, że czas na przygotowanie do zabiegu chorego jest o wiele krótszy, zwłaszcza w przypadku przygotowania chorego do zabiegu w trybie pilnym, na skutek urazu odniesionego w wypadku. Standard polegający na zastosowaniu antybiotykoterapii [2] przed nacięciem skóry i podczas zabiegu operacyjnego może się okazać niewystarczający. Drobnoustroje izolowane $\mathrm{z}$ ran na bloku operacyjnym to np.: Escherichia Coli (22,8\%), Enterococcus spp. (19,1\%), Klebsiella Pneumoniae (8,5\%), Enterobacter spp. (7,7\%), koagulazo ujemne Staphylococci $(7,3 \%)$, Pseudomonas Aeruginosa (7,2\%), Staphilococcus Aureus (4,9\%), Proteus Vulgaris (4,4\%), Morganella Morganii (4,2\%), Acinetobacter Baumanii (3,6\%), Streptococcus spp. (3,5\%), Citrobacter Freundii (2,6\%), Candida spp. (2,3\%), Serratia Marescens (1,2\%), Stenotrophomonas Maltophilia (0,7\%) [3].

Część tych drobnoustrojów to szczepy oporne [4]. Wentylacja mechaniczna także stanowi potencjalną droge transmisji zakażenia [5]. Rozwiązaniem w tym przypadku jest zastosowanie jednorazowych obwodów oddechowych i filtrów zmienianych po każdym pacjencie, w przypadku zastosowania znieczulenia ogólnego.

Zabiegi operacyjne w trybie planowym pozwalają na właściwe przygotowanie, w czasie którego jest czas i miejsce na ochronę chorego przed zakażeniami podczas operacji.

Podczas zabiegu operacyjnego odpowiedzialność za pacjenta spoczywa na zespole anestezjologicznym i operacyjnym. Personel bloku operacyjnego powinien dołożyć wszelkich starań, aby bezpiecznie przeprowadzić chorego przez procedurę. Składową częścią tego procesu jest bezpieczeństwo epidemiologiczne [5].

Przeprowadzone badania [3] wykazały, że czynnikami, które mogą znacząco wpływać na bezpieczeństwo epidemiologiczne chorego na bloku operacyjnym są: wiek pacjenta, płeć, masa ciała, miejsce operowane i rodzaj procedury operacyjnej, ogólny stan zdrowia pacjenta (powyżej III stopnia według klasyfikacji Amerykańskiego
Towarzystwa Anestezjologicznego), jego status palenia papierosów, doświadczenie operatora (operator z krótkim stażem stanowi większe ryzyko infekcji dla pacjenta), rodzaj użytego narzędzia do nacięcia skóry, długość trwania zabiegu - powyżej czterech godzin, obecność drenu w ranie po zabiegu, konieczność śródoperacyjnej transfuzji, pozostawiona siatka w ranie [6].

Innym czynnikiem zakaźnym są drobnoustroje, występujace w drogach oddechowych pacjenta. Dlatego też, pielęgnacja jamy ustnej u pacjenta stanowi prostą i skuteczną strategię w celu zmniejszenia występowania VAP (ang. Ventilator- Associated Pneumonia), u chorych wymagających mechanicznej wentylacji. Drobnoustroje odpowiedzialne za choroby dziąseł oraz przyzębia są stale obecne w jamie ustnej i ich całkowite usunięcie jest praktycznie niemożliwe. Większość bakterii żyjących w jamie ustnej stanowi element fizjologicznej flory pacjenta. Przeprowadzone badania naukowe wykazały, że w przypadku zaniechania higieny jamy ustnej przez okres 10-21 dni, na skutek nagromadzenia się płytki nazębnej, dochodzi do rozwoju zapalenia dziąseł $[7,8,9]$.

Prawidłowe wdrożenie standardów profilaktyki zakażeń szpitalnych przyczynia się do redukcji kosztów terapii[10]. W Polsce koszty wynikające z zakażeń szpitalnych sięgają $800 \mathrm{mln}$ zł rocznie [11].

Poza wyżej wymienionymi, istnieją inne czynniki, które również wpływają na bezpieczeństwo epidemiologiczne tej części szpitala. Można je podzielić na czynniki ludzkie i organizacyjne.

Do czynników organizacyjnych można zaliczyć:

- zwyczaje panujące na bloku operacyjnym, związane z przestrzeganiem procedur;

- presję czasową i dążenie do realizacji planu zabiegów;

- usterki i nieprawidłowości w funkcjonowaniu urządzeń technicznych, np. drzwi do sali operacyjnej (wadliwy system wentylacji powietrza lub zakłócenia w jego funkcjonowaniu);

- niewłaściwa regulacja temperatury otoczenia na sali operacyjnej (zbyt niska temperatura prowadząca do hipotermii u pacjenta ) [12];

- rodzaj zastosowanego znieczulenia (blokady centralne, ze względu na specyfikę działania, doprowadzają do zwiększonej utraty ciepła przez rozszerzone naczynia krwionośne) [13]. 
Brak znajomości obowiązujących procedur i standardów, bądź ich nieprzestrzeganie $z$ innego powodu, może prowadzić do wystąpienia zakażeń krzyżowych (rozprzestrzenienia się drobnoustrojów na następnych pacjentów) [14].

Do najważniejszych elementów profilaktyki zakażeń wpływających na bezpieczeństwo pacjenta w placówkach medycznych zaliczamy:

- skuteczne mycie, dezynfekcję i sterylizację narzędzi oraz sprzętu medycznego wielokrotnego użycia;

- przestrzeganie zasad przechowywania i transportowania sterylnych wyrobów medycznych jednorazowego i wielokrotnego użycia;

- dezynfekcję powierzchni, które mają bezpośredni kontakt $\mathrm{z}$ pacjentem lub $\mathrm{z}$ materiałem biologicznym pochodzącym od pacjentów;

- dezynfekcję pomieszczeń wraz z ich wyposażeniem [15].

Nieprzestrzeganie bądź pominięcie któregokolwiek z powyższych elementów może prowadzić do stworzenia ryzyka przeniesienia infekcji na pacjenta. W imię źle pojętej oszczędności lub z powodu pośpiechu, personel czasami pomija banalne wydawałoby się czynności, co może być brzemienne w skutkach dla chorego.

Do czynników ludzkich można zaliczyć:

- ze strony pacjenta - niska odporność i jej spadki wywołane: nacięciem skóry (wrota zakażenia), stresem związanym z zabiegiem, hipotermią śródoperacyjną [16];

- ze strony personelu - infekcje, rutyna, brak znajomości procedur, nieprzestrzeganie procedur ze względu na efekty uboczne (zmiany atopowe na skórze, zmiany w układzie oddechowym)[17].

Przestrzeganie reżimu sanitarnego przez wszystkich pracowników może mieć zasadniczy wpływ na powikłania związane z zakażeniami szpitalnymi. Pielęgniarki zatrudnione na bloku operacyjnym powinny wykonywać czynności zawodowe z należytą starannością, zgodnie z obowiązującymi procedurami i standardami. W swych działaniach powinny kierować się poczuciem odpowiedzialności za życie i zdrowie osób przebywających w szpitalu. Ciągła edukacja jest nieodzowna w eliminowaniu rutyny zawodowej i negatywnych postaw, mogących mieć wpływ na wzrost ryzyka zakażeń [18]. Higiena rąk ma kluczowe znaczenie w celu minimalizacji jatrogennych zakażeń szpitalnych. Ręce personelu są główną drogą transmisji infekcji. Prawidłowa higiena rąk powinna stać się nieodłączną częścią praktyki klinicznej zespołów anestezjologicznych. Bardzo ważnym aspektem utrzymania prawidłowej higieny rąk jest noszenie krótkich, nie pomalowanych paznokci i zdejmowanie biżuterii.

Rękawice zarówno diagnostyczne jak i sterylne powinny być stale dostępne. Należy pamiętać również, że używanie rękawic nie zwalnia personelu z obowiązku dezynfekcji rąk. Od czasów Ignacego Semmelweisa wiadomo, że prawidłowa higiena rąk jest decydującym czynnikiem w profilaktyce zakażeń przenoszonych przez personel medyczny. Groźba bezradności wobec wielolekoopornych drobnoustrojów skłoniła teoretyków i praktyków do zwrócenia uwagi na higienę rąk z myślą o bezpieczeństwie pacjentów. Przez wiele dziesiątków lat specjaliści zajmujący się kontrolą zakażeń szpitalnych starali się osiągnąć wysoki poziom przestrzegania zasad higieny rąk, jednakże mimo różnych podjętych działań, ten poziom pozostał nadal niski. W literaturze medycznej można znaleźć liczne publikacje analizujące przyczyny niskiego odsetka przestrzegania higieny rąk przez pracowników medycznych, w tym przez lekarzy. Do tychże przyczyn należą, m.in.: zapracowanie i ciągły pośpiech, lekceważące podejście personelu do tej kwestii, brak pozytywnych wzorców, a także luki w wiedzy na temat higieny rąk, „błędne wykonywanie procedury”. Personel pielęgniarski, częściej niż lekarski, wykonuje skuteczne procedury mycia rąk, traktując to jako część rutynowych działań. Warto również zwrócić uwagę na siłę autorytetu. W świetle przeprowadzonych badań obserwacyjnych wynika, że jeśli lider zespołu lekceważył obowiązujące procedury, to pozostała część zespołu też ich nie wykonywała $z$ należytą starannością. Zmęczony i zajęty personel koncentruje się na innych czynnościach i traktuje higienę rąk jako czynność o małym znaczeniu [19].

Ochrona włosów, oczu oraz twarzy stanowi istotny element minimalizacji zakażeń, zarówno personelu, jak i pacjentów. W środowisku sali operacyjnej zalecane jest stosowanie czapek, zmienianych po każdym zabiegu. Podczas zabiegów inwazyjnych należy bezwzględnie stosować jałowe ubrania operacyjne, a skażoną odzież jak najszybciej zmienić [5].

Kolejnym czynnikiem mającym wpływ na transmisję zakażeń jest niewłaściwe postępowanie z lekami i sprzętem do ich podawania. Należy przestrzegać zasad przygotowywania, podawania i przechowywania leków. Strzykawki i inny sprzęt podłączony do linii naczyniowych powinien być traktowany jako skażony. Pozostałe wyposażenie stanowiska znieczulenia także stanowi potencjalną drogę transmisji zakażenia. Opakowania sprzętu jednorazowego powinny być otwierane bezpośrednio przed jego użyciem. Powierzchnie aparatów do znieczulenia i ekrany monitorów należy traktować jako skażone. Powinny być one oczyszczane na bieżąco i zawsze między kolejnymi pacjentami. Wszędzie, gdzie jest to możliwe, należy stosować sprzęt jednorazowego użytku [20].

Szczególną uwagę należy zwrócić na sprzęt używany do intubacji pacjenta. Zalecane są do stosowania jednorazowe łyżki do laryngoskopu oraz jednorazowe prowadnice przy trudnych wielokrotnych intubacjach.

W celu ograniczenia zakażeń zaleca się także stosowanie pakietów interwencji pielęgniarskich, z systemową oceną procedur klinicznych [5].

Podkreśla się, że szczególne czynniki ryzyka infekcji związane $z$ hospitalizacją, to na przykład takie procedury, jak: cewnikowanie pęcherza moczowego, zakładanie linii naczyniowych i opieka nad nimi, postępowanie $z$ chorymi zaintubowanymi [21].

Do czynników, które mogą mieć wpływ na obniżenie odporności pacjenta, można zaliczyć hipotermię okołooperacyjną. Stan obniżenia temperatury centralnej poniżej 36 st. C jest określany jako hipotermia okołooperacyjna, będąca jednym z powikłań związanych ze znieczuleniem i zabiegiem operacyjnym. Z przeprowadzonych badań 
naukowych wynika, że zjawisko niezamierzonej hipotermii występuje u 50-90\% operowanych pacjentów. Do powikłań hipotermii zaliczamy zaburzenia ze strony układu oddechowego, układu krążenia, zaburzenia krzepnięcia, zaburzenia elektrolitowe, większą podatność na zakażenia, zaburzony proces gojenia się ran czy ograniczony metabolizm leków. Hipotermia wpływa na częstość występowania zakażeń miejsca operowanego i szybkość gojenia się ran. W wielu publikacjach wykazano wpływ zaburzonej temperatury ciała na układ immunologiczny. Redukcja temperatury głębokiej zaburza leukopoezę, wpływa negatywnie na produkcję immunoglobulin, a także decyduje o zmniejszonej krzepliwości. Hipotermia trzykrotnie zwiększa ryzyko wystąpienia zakażenia miejsca operowanego. Przyczyny zakażeń w tym przypadku mają różne podłoże. $Z$ jednej strony ograniczony dopływ tlenu do miejsca operowanego (wazokonstrykcja) oraz $\mathrm{z}$ drugiej - reakcja układu odpornościowego pacjenta [22, $23,24,25]$.

Blok operacyjny stanowi wydzieloną strefę szpitala o najwyższym stopniu czystości. Przestrzeganie procedur i zasad postępowania oraz zachowania na bloku operacyjnym przez cały pracujący tam zespół sprawi, że strefa ta będzie bezpieczna zarówna dla pacjenta jak i zespołu medycznego [5].

\section{PODSUMOWANIE}

Zakażenia, których źródłem jest czynnik wywołujący, pochodzący z bloku operacyjnego, są dużym problemem, który znacząco wpływa na stan pacjenta, rokowanie, inne powikłania, a w efekcie - na ostateczne wyniki terapii pacjenta i jej ocenę. Działania prewencyjne podejmowane w celu ochrony pacjentów, a gdy to niemożliwe - zmniejszenie narażenia, często wydają się być nieskuteczne lub niewystarczające.

Poszukiwanie źródeł niepowodzeń w walce z zagrożeniem zakażeniami na bloku operacyjnym staje się jednym z priorytetów, których celem jest doskonalenie jakości świadczonych usług.

Źródeł niepowodzeń w tej dziedzinie można doszukiwać się w niedoskonałych procedurach, wadliwej organizacji pracy, usterkach technicznych, rutynie w wykonywaniu zawodowych czynności przez personel medyczny, lub przeciwnie - krótkim stażu pracy i braku doświadczenia.

Nie można także zapominać o zakaźnym potencjale, którego źródłem jest sam pacjent. W związku z tym całkowite wyeliminowanie zagrożeń wydaje się być niemożliwe, mimo doskonalenia procedur, szkoleń i usprawnień organizacyjnych i technicznych.

\section{ORCID}

Jolanata Sułek (D) https://orcid.org/0000-0003-1114-0095

\section{REFERENCES/PIŚMIENNICTWO}

1. Culver DH, Horan TC, Gaines RP, et al. Surgical wound infection rates by wound class, operative, and patient risk index. The American Journal of Medicine. 1991; 91 (suppl 3B): 152-157.

2. Hryniewicz W, Kulig J, Ozorowski T, et al. Stosowanie antybiotyków w profilaktyce okołooperacyjnej. Warszawa: Wyd. Narodowy Instytut Leków; 2011.

3. Isik 0 , Kaya $E$, Dundar HZ, et al. Surgical site infection: Re-assesment of the risk factors. Chirurgia. 2015; 110: 457-461.

4. Rożkiewicz D. Szczepy oporne w środowisku szpitalnym. Białystok: Wyd. Medilab; 2019.

5. Jadczak M, Zdun A, Witt P. Obwody oddechowe i sprzęt anestezjologicznypotencjalne źródła zakażeń w anestezjologii. Pielęgniarstwo w Anestezjologii i Intensywnej Opiece. 2016; 2 (4): 105.

6. Kaye KS, Sloane R, Sexton DJ, et al. Risk factors for surgical site infections in older people. Journal compilation The American Geriatrics Society. 2006; 54: 391-396.

7. Mędrzycka-Dąbrowska W. Program higieny jamy ustnej jako profilaktyka zapalenia płuc u chorych wentylowanych mechanicznie. Pielęgniarstwo w Anestezjologii i Intensywnej Opiece. 2016; 2 (2): 57.

8. Feider LL, Mitchell P, Bridges E. Oral care practices for orally intubated critically ill adults. Am J Crit Care. 2010; 19 (2), 175-183.

9. Mędrzycka-Dąbrowska W, Dąbrowski S, Basiński A. Aktualne zalecenia w pielęgnacji jamy ustnej u pacjentów zaintubowanych i wentylowanych mechanicznie - przegląd piśmiennictwa. Anest Ratow. 2012; 6: 221-230.

10. Lisovoy $G$, Fraeman $K$, Huthins $V$, et al. Surgical site infection: incidence and impact on hospital utilization and treatment costs. American Journal Infection Control. 2009; 37: 387-397.

11. Mączyńska A, Korbecka-Paczkowska M. Światowe standardy profilaktyki zakażeń szpitalnych- dzielimy się wiedzą i doświadczeniami. Zakażenia. 2016; 6: 25.

12. Rozporządzenie Ministra Zdrowia z dnia 26 czerwca 2012 r. w sprawie szczegółowych wymagań, jakim powinny odpowiadać pomieszczenia i urządzenia podmiotu wykonującego działalność leczniczą. Dz. U.2012, p0z. 739.

13. Larsen R. Anestezjologia. Wrocław: Wyd. Urban\& Partner; 2013, s. 163-193.

14. Wojciechowski A. (opr.) Oparty na dowodach naukowych model przenoszenia drobnoustrojów przez ręce podczas opieki nad pacjentem. Zakażenia. 2016; 2(16):50.

15. Ciuruś M. Znaczenie dezynfekcji i sterylizacji w profilaktyce zakażeń. Zakażenia. 2017; 5 (17).

16. Montewka M, Skrzek A, Plewik D, et al. Zakażenia miejsca operowanego charakterystyka czynników ryzyka, endogennych źródeł zakażenia i metody zapobiegania. Post. Mikrobiol. 2012; 3 (51): 227-235.

17. Kieć-Świerczyńska M, Kręcisz B. Alergiczne kontaktowe zapalenie skóry u pracowników służby zdrowia. Służba Zdrowia. 2001; 71-72.

18. Tokarski Z. Zakażenia na bloku operacyjnym [w]: Denys A, red. Zakażenia szpitalne w wybranych oddziałach. Warszawa: Wyd. ABC a Wolters Kluwer business; 2013, s. 233.

19. Sokół-Leszczyńska B, Leszczyński P. Dlaczego higiena rąk jest ciągle problemem W środowisku medycznym- czy znamy skuteczne rozwiązanie? Zakażenia. 2017;4 (17): 5 .

20. Budnik-Szymoniuk M, Wilińska A. Bezpieczna linia naczyniowa- znaczenie dla zarządzania ryzykiem w szpitalu. Zakażenia. 2010; 4(10): 107.

21. Bulanda M, Wójkowska-Mach J. Zakażenia szpitalne w jednostkach opieki zdrowotnej. Warszawa: Wyd. PZWL; 2016

22. Szmydt M, Motyssek K. Niezamierzona hypotermia okołooperacyjna jako czynnik zwiększający ryzyko różnych powikłań, w tym zakażeń. Zakażenia. 2016; 5 (16):43.

23. Adamiec A, Misiołek H. Niezamierzona hipotermia okołooperacyjna a zakażenie miejsca operowanego. Forum Zakażeń. 2014; 5(6): 349-353

24. Horosz B, Malec-Milewska M. Hipotermia okołooperacyjna- czynnik zwiększający ryzyko powikłań infekcyjnych. Forum Zakażeń. 2014; 5(2): 67-71.

25. Qadan M, i wsp. Hypothermia and surgery: Immunologic mechanisms for current practice. Ann Surg. 2009; 250(1):134-140.

Manuscript received/Praca zgłoszona do czasopisma: 03.06.2019

Manuscript accepted/Praca zaakceptowana do druku: 08.04.2020

Translation/Tłumaczenie: Languagehause, ul. Krzywa 7, Nowy Targ. 